\title{
Predictive Value of Monocyte to High-Density Lipoprotein Cholesterol Ratio (MHR) in Schizophrenia Patients with Stable Coronary Artery Disease Stabil Koroner Arter Hastalığı Olan Şizofreni Hastalarında Monosit/Yüksek Yoğunluklu Lipoprotein (MHR) Oranının Öngördürücülüğü
}

\author{
Mustafa Candemir (D) 2Alparslan Cansız
}

\begin{abstract}
Gazi University, Faculty of Medicine, Department of Cardiology, Ankara Turkey

${ }^{2}$ Selçuk University, Faculty of Medicine, Department of Psychiatry, Konya, Turkey

\section{Correspondence}

Alparslan CANSIZ, Selçuk University Faculty of Medicine, Department of Psychiatry, Konya, Turkey

E-Mail: alpcan2861@gmail.com

How to cite ?

Candemir M, Cansiz A. Predictive Value of Monocyte to High-Density Lipoprotein Cholesterol Ratio (MHR) in Schizophrenia Patients with Stable Coronary Arter Patients wenel Tip Derg. 2022.32(1):7783
\end{abstract}

\begin{abstract}
Aim: We aimed to investigate whether the monocyte/high-density lipoprotein ratio (MHR) has a potential value in the diagnosis of schizophrenia and in predicting the presence of comorbid coronary artery disease (SPCAD).

Material and Method: A total of 281 participants were enrolled in this cross-sectional study. Of the participants, 85 (Group 1) were diagnosed with schizophrenia and stable coronary artery disease, and 92 (Group 2) were diagnosed with only schizophrenia. 104 (Group 3) participants in the control group had no disease.

Results: MHR was highest in group 1 and higher in group 2 than in group 3. Group 1 was 18.91 (13.38-23.60) group 2: $13.68(11.11-16.66)$ and group 3: $12.50(9.13-15.68)$, respectively; $p<0.001$ for both). Conversely, HDL was the lowest in group 1, while it was lower in group 2 than in group 3 (38.52 \pm 9.45 vs. $42.76 \pm 9.12$ vs. $47.00 \pm 11.87$, respectively $p<0.05$ for both). The cutoff value of MHR for SPCAD was 12.77 , with a sensitivity of $79 \%$ and a specificity of $43 \%$. This value for SP was 10.73 , with a sensitivity of $79 \%$ and a specificity of $50 \%$.

Conclusion: High MHR which indicates an enhanced inflammation and oxidative stress was found a significant and independent marker in SP and SPCAD.
\end{abstract}

Keywords: Coronary artery disease, inflammation, monocyte to high-density lipoprotein ratio, oxidative stress, schizophrenia

Öz

Amaç: Bu çalışmada şizofreni ve stabil koroner arter hastalığı olan şizofreni hastalarında (SKAH-S) monosit/yüksek yoğunluklu lipoprotein oranının (MHO) tanıda öngördürücü değerinin olup olmadığını araştırmayı amaçladık.

Gereç ve yöntem: Bu kesitsel çalışmaya toplam 281 katılımcı alındı. Katıımcıların 85 'ine şizofreni ve stabil koroner arter hastalı̆ı̆ (Grup 1), 92 'sine ise sadece şizofreni (Grup 2) tanısı konuldu. Kontrol grubundaki 104 katılımcının (Grup 3) ise hiçbir hastalığı yoktu.

Bulgular: MHO grup 1'de en yüksek iken grup 2'de grup 3'e göre daha yüksekti (grup 1: 18.91 (13.38-23.60); grup 2: 13.68 (11.11-16.66); grup 3: 12.50 (9.13-15.68); her iki karşılaştırma için $p<0.001$ ). Buna zi† olarak, $\mathrm{HDL}$ grup 1'de en düş̈̈ iken grup 2'de grup 3'e göre daha düșüktü (grup 1: 38.52 + 9.45; grup 2: $42.76 \pm 9.12$; grup 3: $47.00 \pm 11.87$; her iki karsslaștırma için $p<0.05$ ). MHO' nun kesme puanı stabil koroner arter hastalığı olan şizofreni hastalarında 12.77 ve üzeri alındığında duyarlllik \%79, özgüllük ise \%43 bulundu. Sadece şizofreni hastalarında ise kesme değeri 10.73 ve üzeri alındığında duyarllık \% 79, özgüllük ise \% 50 bulundu.

Sonuç: Artmış inflamasyon ve oksidatif stresi gösteren yüksek MHO, şizofreni ve stabil koroner arter hastalığı olan şizofreni hastalarında önemli ve bağımsız bir belirteç olarak bulundu.

Anahtar kelimeler: Koroner arter hastalığı, inflamasyon, monosit/yüksek yoğunluklu lipoprotein oranı, oksidatif stres, şizofreni

\section{Introduction}

Schizophrenia is a serious mental disorder that manifests cytokines, inflammatory proteins, and tissue levels reveal itself with disturbances in thought, perception and the role of the immune system and inflammation in behavior, and causes severe morbidity and mortality. schizophrenia (3-5). Studies on oxidative stress show that It is known that its lifetime prevalence is approximately there is a decreased antioxidant capacity in addition $1 \%$ (1). The first hypotheses proposed in schizophrenia, to increased oxidant activity in schizophrenia (6). It has which has a multi-factorial etiology, pointed to been reported that both pro-inflammatory markers neurotransmitter imbalance. In recent genetic studies, and oxidative stress are increased independent of genetic regions associated with oxidative stress and antipsychotic treatment $(6,7)$. inflammation stand out (2). Studies on blood cells, 
Studies reveal that oxidative stress and inflammation may be effective not only in the etiology but also in the development of co-morbid conditions observed in the disease. It has been shown that the frequency of cardiovascular diseases increases 1.20 to 1.81 times and mortality increases 2 to 3 times in patients with schizophrenia $(3,6)$. Genetic factors, insulin resistance, impaired hypothalamic-hypopituitary-adrenal axis, increased oxidative stress and inflammatory response are thought to facilitate the development of cardiovascular diseases in patients with schizophrenia by forming a common ground (8-10).

Inflammation and oxidative stress are known to play an important role in the development and progression of atherosclerosis (11). Macrophages and monocytes are the most important cells that mediate the secretion of pro-inflammatory and pro-oxidant cytokines at inflammation site (12). These cells were determined to provide the release of inflammatory cytokines and tissue remodeling in the pathophysiology of coronary artery disease (13). Conversely, high-density lipoprotein cholesterol (HDL-C) prevents the formation of atherosclerosis by creating a defense mechanism in endothelial cells with its antioxidant effect $(14,15)$. This result has been supported by many studies (16). In addition, HDL-C inhibits monocyte activation and the proliferation and differentiation of monocyte progenitor cells (17). The ratio of these two parameters (monocyte/HDL-C ratio (MHR)) has been identified as a new marker, as high monocyte count and low HDL-C play a role in diseases with inflammatory and oxidative stress in the pathophysiology. This ratio is a relatively simple and inexpensive indicator of systemic inflammation obtained from the total blood count. In addition, this marker has predictive and prognostic importance in cardiovascular diseases such as coronary artery disease $(18,19)$. In the study of Kızltunç et al., it was found that MHR was associated with the severity of coronary artery disease in 760 patients who underwent coronary angiography under elective conditions (20). In a recent study, 74 schizophrenic patients were compared with healthy controls for MHR. In that study, MHR was higher in the patient group than in healthy individuals (21).

MHR, which is a practical and inexpensive instrument, can be used to detect early systemic inflammatory events such as cardiovascular disease in patients with schizophrenia. However, there is no study investigating MHR in schizophrenia patients with coronary artery disease in the literature (SPCAD). For this reason, our study has two aims; i- to determine the diagnostic value of MHR in patients with schizophrenia, ii- The capacity of MHR to predict the presence of coronary artery disease in patients with schizophrenia.

\section{Material and Method}

All subjects were retrospectively reviewed admitted to a tertiary hospital with schizophrenia between January 2009 and February 2020. The demographic and clinical data of the patients were obtained from their electronic medical records. Patients admitted with a diagnosis of schizophrenia for at least 6 months were included. In addition, the diagnosis of schizophrenia was confirmed by at least 2 psychiatrists. The diagnosis of the patients was made according to the 4th edition of the Diagnostic and Statistical Manual of Mental Disorders (DSM-IV-TR) (22). All patients were between 18-65 years old. Patients with an active infection during the blood draw, acute coronary syndrome, history of acute or chronic liver or kidney disease, autoimmune disease, cancer, hematological disorders, severe valvular disease, rheumatic disease or using antihyperlipidemic drugs were planned to be excluded from the study. Among the patients diagnosed with schizophrenia, patients with stable angina pectoris were selected. After all, it was determined that 91 patients with schizophrenia were diagnosed with stable angina pectoris. Six of these patients had missing file information. Thus, 85 schizophrenia patients with coronary disease were included in the study as Group 1. The diagnosis of stable angina pectoris was made in accordance with the criteria specified in the guidelines. All patients with stable angina pectoris underwent coronary angiography. Coronary angiographies of the patients were performed after the blood results were evaluated in the study. Group 2 $(n=92)$ included patients with schizophrenia who were age-matched to the first group and did not have any cardiac diagnosis. In order to increase the accuracy of the analyzes, the control group was also included in the study (group 3, $n=104$ ). This group was selected as age-matched to the previous groups among the individuals who were not found to have any pathology when they were admitted to the cardiology outpatient clinic with any cardiac complaints. The demographic and clinical data of the patients were obtained from their electronic medical records.

An approval (approval no. 2020/483) of the Local Ethics Committee of Selçuk University was obtained for the research.

\section{Laboratory Analysis}

Routine blood tests obtained in the last three months in the psychiatry and cardiology clinics to which the participants applied were included in the analysis. Basic hematologic parameters, such as monocyte count were measured with an auto analyzer. Serum total cholesterol, triglyceride, and HDL-C concentrations were analyzed by using an automated chemistry analyzer. Serum low-density lipoprotein cholesterol (LDL-C) values were estimated by the formula of Friedewald or directly measured if triglyceride $>400 \mathrm{mg} / \mathrm{dL}$. MHR ratio was calculated by division of monocyte count by HDL-C.

\section{Statistical Analysis}

Statistical analyses were performed using the SPSS software version 23.0 (SPSS Inc, Chicago, IL, USA). The 
Kolmogorov-Smirnov method was used to test the distribution pattern. Data were presented as mean and standard deviation, median and interquartile range, or proportions. The Chi-square test was used to compare the proportions of the different groups. One-way analysis of variance or Kruskal-Wallis tests were used to compare continuous variables among different groups according to the distribution pattern of the variable. When an overall significance was observed in a normally distributed variable, the post hoc Tukey's test was performed. When an overall significance was observed in an abnormally distributed variable, pairwise differences were evaluated using the Mann-Whitney $U$ test and the Bonferroni correction was applied to adjust for multiple comparisons. Stepwise multivariate logistic regression analysis was done to examine the association between the functional significance of the lesions and other variables. Variables with $\mathrm{P}<0.25$ in univariate logistic regression were included in a multivariate logistic regression model. In the logistic regression model, MHR level was assumed to be a binary variable according to the cutoff point detected in the receiver operating characteristic (ROC) curve analysis. A difference with a p-value $<0.05$ was considered statistically significant.

\section{Results}

A total of 281 participants were enrolled in the study. Of the participants, 85 (Group 1; mean age $37.06 \pm$ 11.27, 22 females and 63 males) were diagnosed with schizophrenia and stable coronary artery disease and 92 (Group 2; mean age $37.36 \pm$ 10.50, 35 females and 57 males) were diagnosed only schizophrenia. 104 (Group 3; mean age $35.40 \pm 11.01$, 49 females and 55 males) participants in the control group had no disease. Demographic characteristics were similar across all groups. There were no significant differences between groups with respect to the serum biochemical parameters of glucose, creatinine, hemoglobin, platelets, lymphocyte, ALT, AST, total cholesterol, triglycerides, LDL-C (Table 1).

Monocytes count (700.00 (575.00-800.00) vs. 600.00 (500.00-700.00) vs. 500.00 (400.00-675.00) vs, $\mathrm{p}<0.001)$ and MHR (18.91 (13.38-23.60) vs.13.68 (11.11-16.66) vs. 12.50 (9.13-15.68), $p<0.001)$ were significantly higher in group 1 than the other group 3, while HDL-C 138.52 \pm 9.45 vs. $42.76 \pm 9.12$ vs. $47.00 \pm 11.87, p<0.001$ ) was lower. The cutoff value of MHR for schizophrenia was 10.73 , with a sensitivity of $79 \%$ and a specificity of $50 \%$,

Table 1. Baseline characteristics and laboratory findings of the study participants.

\begin{tabular}{|c|c|c|c|c|}
\hline & Group $1(n=85)$ & Group 2 (n=92) & Group 3 (Control) $(n=104)$ & $p$ \\
\hline Age, mean (SD), years & $37.06 \pm 11.27$ & $37.36 \pm 10.50$ & $35.40 \pm 11.01$ & 0.40 \\
\hline Sex (Male), n (\%) & $63(74.1)$ & $57(62.0)$ & 55 (52.9) & 0.10 \\
\hline Hypertension, n (\%) & $51(60)$ & $64(69.6)$ & $61(58.7)$ & 0.24 \\
\hline Diabetes mellitus, n (\%) & $32(37.6)$ & $28(30.4)$ & $27(26)$ & 0.22 \\
\hline Smoke, n (\%) & $26(31)$ & $31(34)$ & $36(35)$ & 0.83 \\
\hline Dyslipidemia, n (\%) & $43(50.6)$ & $43(46.7)$ & $36(34.6)$ & 0.16 \\
\hline$E F, \%$ & $60.00(52.00-65.00)$ & $62.00(55.00-65.00)$ & $65.00(61.00-67.00)$ & 0.15 \\
\hline Glucose, mg/dl & 98.00 (91.00-147.50) & 102.00 (93.00-129.00) & 101.00 (91.00-125.00) & 0.26 \\
\hline BUN, mg/dl & $17.59 \pm 6.06$ & $16.34 \pm 4.94$ & $15.75 \pm 6.63$ & 0.12 \\
\hline Creatine, mg/dl & $0.88(0.80-1.10)$ & $0.82(0.72-0.98)$ & $0.82(0.70-0.97)$ & 0.07 \\
\hline WBC count, $\left(\times 10^{3} / \mathrm{ml}\right)$ & $8.80(7.20-10.25)^{*}$ & 7.55 (6.60-9.10) & 7.45 (6.30-8.70) & 0.01 \\
\hline Hemoglobin, gr/dl & $13.74 \pm 1.76$ & $13.53 \pm 2.09$ & $13.29 \pm 1.68$ & 0.26 \\
\hline RDW, \% & $14.00 \pm 1.72$ & $13.00 \pm 1.32$ & $13.85 \pm 1.81$ & 0.31 \\
\hline PLT, $\left(\times 10^{3} / \mathrm{ml}\right)$ & $241.00(193.50-277.00)$ & $235.00(186.25-286.00)$ & $235.00(194.25-286.00)$ & 0.34 \\
\hline Neutrophil count & $5300.00(4500.00-6750.00)^{*}$ & $4600.00(3700.00-5450.00)$ & $4450.00(3500.00-5500.00)$ & $<0.001$ \\
\hline Lymphocyte count & $2257.06 \pm 907.08$ & $2275.76 \pm 930.81$ & $2373.26 \pm 775.76$ & 0.90 \\
\hline Monocyte count & $700.00(575.00-800.00)^{*}$ & $600.00(500.00-700.00)^{*}$ & $500.00(400.00-675.00)^{*}$ & $<0.001$ \\
\hline AST u/I & $22.00(16.00-29.00)$ & $21.00(17.00-27.00)$ & $20.00(17.00-25.25)$ & 0.22 \\
\hline ALT U/l & $21.50(15.00-31.00)$ & $20.00(14.75-30.25)$ & $19.00(14.00-27.00)$ & 0.07 \\
\hline Triglyceride mg/dl & $148.24 \pm 73.75$ & $160.88 \pm 82.83$ & $148.67 \pm 85.52$ & 0.49 \\
\hline Total cholesterol, mg/dl & $185.82 \pm 44.74$ & $185.36 \pm 56.71$ & $197.03 \pm 44.89$ & 0.17 \\
\hline $\mathrm{LDL}, \mathrm{mg} / \mathrm{dl}$ & $116.03 \pm 41.40$ & $113.16 \pm 45.72$ & $122.93 \pm 38.16$ & 0.24 \\
\hline $\mathrm{HDL}, \mathrm{mg} / \mathrm{dl}$ & $38.52 \pm 9.45^{*}$ & $42.76 \pm 9.12^{*}$ & $47.00 \pm 11.87^{*}$ & $<0.001$ \\
\hline MHR & $18.91(13.38-23.60)^{*}$ & $13.68(11.11-16.66)^{*}$ & $12.50(9.13-15.68)^{*}$ & $<0.001$ \\
\hline \multicolumn{5}{|c|}{$\begin{array}{l}\text { ALT: alanine aminotransferase, AST: aspartate aminotransferase, BUN: Blood Urea Nitrogen, HDL: high-density lipoprotein cholesterol, LDL: } \\
\text { low-density lipoprotein cholesterol, MHR: monocyte to high-density lipoprotein cholesterol ratio, PLT: platelets, RDW: Red cell distribution } \\
\text { width, WBC: white blood cells. " denotes statistically significant cells after Tukey or Games-Howell adjustment. }\end{array}$} \\
\hline
\end{tabular}


(AUC: $0.652 ; 95 \%$ confidence interval (Cl): 0.575-0.729; $\mathrm{p}<0.001$ ) on ROC curve analysis (Figure 1). Multivariate logistic regression analysis including hypertension, dyslipidemia, glucose, ALT, total cholesterol, LDL-C, MHR demonstrated that MHR was the only independent predictor of schizophrenia (OR: 1.438, Cl: 1.268-1.631, $\mathrm{P}<0.001$ ) (Table 2).

The cutoff value of MHR for schizophrenia and stable coronary artery disease was 12.77 , with a sensitivity of $79 \%$ and a specificity of $43 \%$ (area under the curve $(A \cup C): 0.695,95 \%$ confidence interval (Cl):0.616$0.775 ; p<0.001$ ) on ROC curve analysis (Figure 2). Three models were generated by multivariate logistic regression analysis to predict SPCAD. MHR was found to be the best independent predictor in all models (OR: 1.471, Cl: 1.283-1.688, $\mathrm{P}<0.001$ ) (Table 3).
Figure 1. Receiver operating characteristic (ROC) curve analysis of MHR in schizophrenia patients.

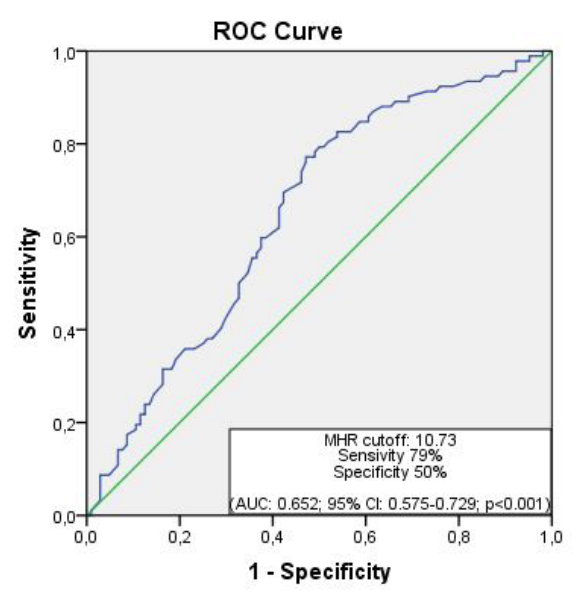

Diagonal segments are produced by ties.

AUC: area under the curve; $\mathrm{Cl}$ : confidence interval; MHR: monocyte to high-density lipoprotein cholesterol ratio.

Table 2. Multivariate logistic regression analysis showing independent predictors in schizophrenia patients.

\begin{tabular}{|c|c|c|c|c|}
\hline & \multicolumn{2}{|l|}{ Univariate } & \multicolumn{2}{|l|}{ Multivariate } \\
\hline & OR $(95 \% \mathrm{Cl})$ & $p$ & OR $(95 \% \mathrm{Cl})$ & $p$ \\
\hline Sex (Male) & $1.396(0.789-2.470)$ & 0.252 & - & - \\
\hline Hypertension & $1.611(0.892-2.910)$ & 0.114 & $1.138(0.509-2.546)$ & 0.753 \\
\hline Dyslipidemia & $1.658(0.932-2.947)$ & 0.085 & 1.761 (0.807-3.845) & 0.155 \\
\hline Glucose & 1.004 (0.998-1.010) & 0.159 & 1.005 (0.998-1.013) & 0.166 \\
\hline ALT & $1.019(0.994-1.045)$ & 0.132 & $1.018(0.985-1.051)$ & 0.292 \\
\hline Total cholesterol & $0.995(0.990-1.001)$ & 0.111 & 1.014 (0.996-1.033) & 0.129 \\
\hline LDL & $0.994(0.988-1.001)$ & 0.106 & $0.980(0.959-1.001)$ & 0.063 \\
\hline MHR & $1.422(1.264-1.600)$ & $<0.001$ & $1.438(1.268-1.631)$ & $<0.001$ \\
\hline
\end{tabular}

Table 3. Multivariate logistic regression analysis showing independent predictors in schizophrenia patients with coronary artery disease.

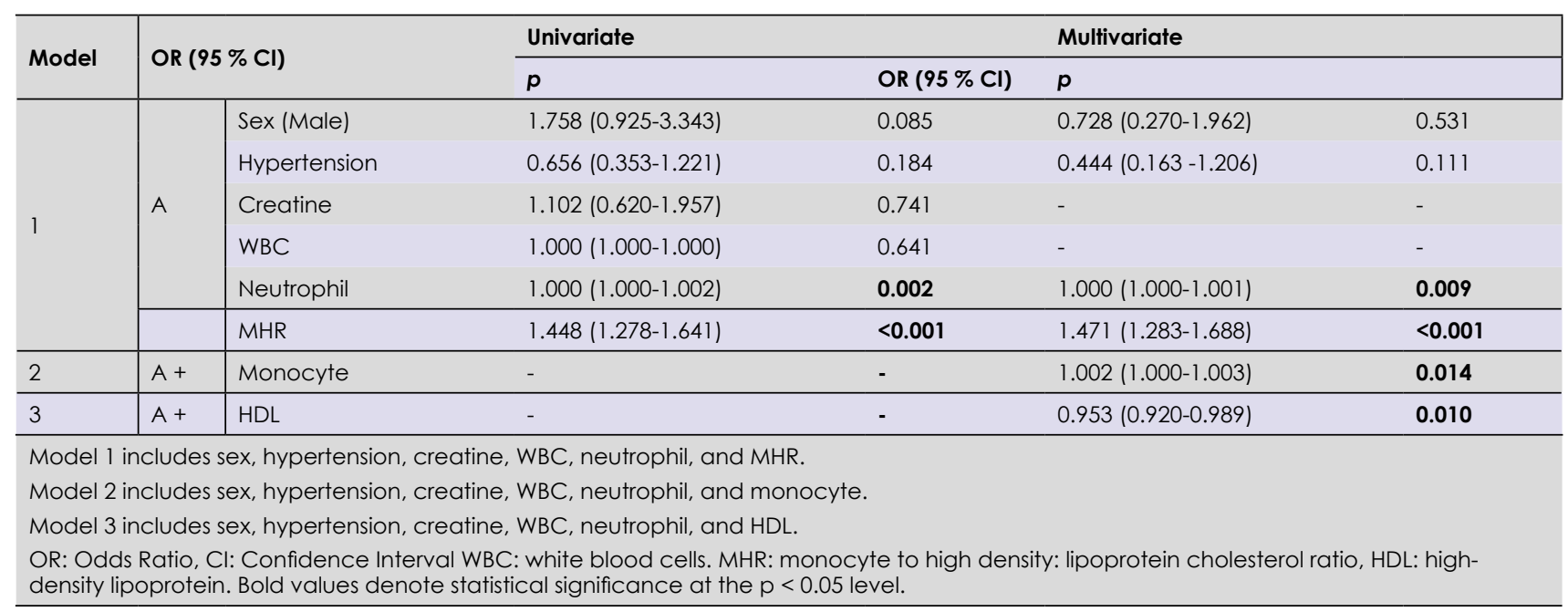


Figure 2. Receiver operating characteristic (ROC) curve analysis of MHR in schizophrenia patients with coronary artery disease.

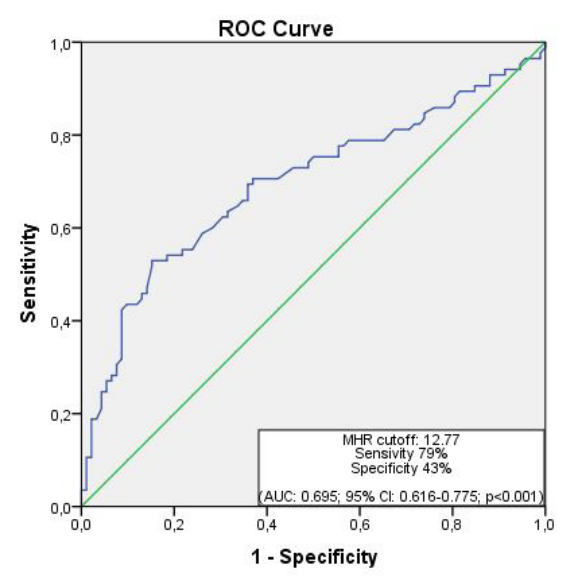

Diagonal segments are produced by ties.

AUC: area under the curve; $\mathrm{Cl}$ : confidence interval; MHR: monocyte to high-density lipoprotein cholesterol ratio.

\section{Discussion}

In our study, MHR was found higher in SPCAD compared to schizophrenia patients without coronary artery disease and the control group. In addition, increased MHR was found to have a diagnostic value both for schizophrenia and for predicting the presence of coronary artery disease in schizophrenia patients.

Genetic studies reveal the prominent role of inflammatory parameters in schizophrenia. Among the single nucleotide polymorphisms detected in schizophrenia, it has been shown that the strongest relationship with the disease is in the genes responsible for the complement system (C4) (23). Studies show that the $\mathrm{C} 4$ complement protein enables the synapses to be pruned by microglia and that the C4A protein is expressed more in schizophrenia patients than in controls. It is thought that neuron-microglia interaction through the complement system plays a role in the pathogenesis of schizophrenia. In addition to many parameters in the detection of systemic inflammation, whole blood and biochemistry measurements offer practical and effective methods. In a recent metaanalysis evaluating the studies investigating neutrophillymphocyte ratio (NLR), which is shown as one of these, it has been shown that NLR increases both in the first episode and in chronic schizophrenia patients (3). It has also been reported that there is a linear relationship between increased NLR and increased disease severity. Studies evaluating monocytes in patients with schizophrenia state that the number of monocytes increases in both follow-up and first-episode patients $(24,25)$. It is stated that the increase in monocytes in patients with schizophrenia is a peripheral indicator of microglia activation in the brain (24). Our findings show that MHR increases similarly to NLR in patients with schizophrenia compared to controls, and monocyte activation can also be mentioned in patients in our sample.
It is known that lipid metabolism is impaired in patients with schizophrenia. In a meta-analysis including 19 studies, it was revealed that first-episode psychosis patients who did not use any medication had a decrease in total cholesterol and HDL-C levels and an increase in triglyceride levels (26). Based on this, low HDL-C levels in schizophrenia patients are considered to be associated with both the etiology of schizophrenia and increased cardiovascular comorbidity (27). Consistently with the literature, in our study, HDL-C levels were lower in schizophrenia patients with coronary artery disease compared to both the control group and schizophrenia patients without cardiovascular disease. Although the cross-sectional design of our study does not allow interpreting the causal relationship, it can be stated that lipid metabolism should be closely monitored in patients with schizophrenia. In addition, ROC analysis shows that MHR can be used as a new biomarker in patients with schizophrenia.

Inflammation and oxidative stress are well-known mechanisms during the development and progression of atherosclerosis (13). It has been stated that the number of monocytes, one of the basic cells of the human immune system, is an independent predictive marker in atherosclerotic plaque formation and plaque progression (28). Since the sensitivity of monocytes to chemokines increases in hypercholesterolemic patients, it has been expressed that these cells play a more prominent role in the atherosclerotic process (29). HDL-C, which reduces the effects of the hypercholesterolemic environment, has antiinflammatory and anti-oxidant properties and is known as a negative acute phase reactant, has an important role in preventing the formation of atherosclerosis (2932). HDL-C inhibits active monocytes (33) and inhibits the endothelial expression of adhesion molecules, preventing monocyte passage from the artery endothelium (34). In addition, HDL-C has determined shown to play an important role in protection against atherosclerosis, unlike monocytes (35) and $\mathrm{HDL}-\mathrm{C}$ is an important marker for the prognosis of cardiovascular diseases (36). Kizlltunç et al. (20) found they MHR was associated with the severity and extent of coronary artery disease. MHR has also been proven to be an independent marker that predicts in-hospital mortality and 5-year major adverse cardiovascular events (MACE) in patients with ST-segment elevation myocardial infarction (32). Based on all these study results, it can be considered that MHR is a valuable marker in atherosclerotic heart diseases and deserves to be investigated in other cardiovascular conditions.

Cardiovascular diseases are the leading cause of early death in patients with schizophrenia. It has been reported that the life expectancy in schizophrenia patients decreases by 15-20 years compared to the normal population due to cardiovascular diseases (37). In addition, it is known that patients with schizophrenia go to examinations less for their physical 
health and talk less about their complaints (38). Therefore, early diagnosis of cardiovascular diseases and other metabolic disturbances is very important in schizophrenia patients. Few biomarker studies have been conducted to define cardiovascular disease risk in patients with schizophrenia (39). Our research reveals that increased MHR has high power in predicting stable coronary artery disease in patients with schizophrenia. This information suggests that systemic inflammation is an important mediator of the development of cardiovascular disease in patients with schizophrenia, as well as known environmenta risk factors. As a marker of systemic inflammation and oxidative stress, MHR could provide information on the common origins of schizophrenia and cardiovascular disease.

Our study has some limitations. First is the relatively small sample size and its retrospective design. Second, since our study was in a cross-sectional design, it does not provide information about which disease started first. Third, antipsychotic drugs have some effects on cardiac functions and we could not test whether the drugs taken by the patients had an effect on MHR. Fourth, it is not documented that patients who were determined to have no coronary artery disease from their history and records have normal coronaries. Fifth, only those with a diagnosis of coronary artery disease were not included in the analysis. Another limitation is that although the exclusion criteria were applied to the control group, the control group may not reflect and the characteristics of the general population due to the design of the study. Finally, other inflammatory markers such as CRP and oxidative stress markers have not been evaluated.

\section{Conclusion}

Our study is the first to investigate MHR in patients with schizophrenia and reveal its relationship with coronary artery disease. We found that MHR, which can be easily obtained from complete blood count and biochemistry measurement, was higher in patients with schizophrenia. In addition, our study has added a new observation to the literature that a higher MHR level may have a diagnostic value for coronary artery disease, especially in patients with schizophrenia. However, our findings should be confirmed with largescale prospective studies.

\section{Acknowledgments}

Declaration of Conflicting Interests

The Authors declare that there is no conflict of interest.

\section{Funding}

The authors received no financial support for the research, authorship, and/or publication of this article.

\section{References}

1.McCutcheon RA, Reis Marques T, Howes OD. Schizophrenia-An Overview. JAMA psychiatry. 2019:1-10.

2.Liu J, Li M, Luo XJ, SU B. Systems-level analysis of risk genes reveals the modular nature of schizophrenia. Schizophrenia research. 2018;201:261-9.

3.Trépanier MO, Hopperton KE, Mizrahi R, Mechawar N, Bazinet RP. Postmortem evidence of cerebral inflammation in schizophrenia: a systematic review. Molecular psychiatry. 2016;21 (8):1009-26.

4.Gallego JA, Blanco EA, Husain-Krautter S, Madeline Fagen E, MorenoMerino P, Del Ojo-Jiménez JA, et al. Cytokines in cerebrospinal fluid of patients with schizophrenia spectrum disorders: New data and an updated meta-analysis. Schizophrenia research. 2018;202:64-71.

5.Karageorgiou V, Milas GP, Michopoulos I. Neutrophil-to-lymphocyte ratio in schizophrenia: A systematic review and meta-analysis. Schizophrenia research. 2019;206:4-12.

6.Flatow J, Buckley P, Miller BJ. Meta-analysis of oxidative stress in schizophrenia. Biological psychiatry. 2013;74(6):400-9

7.Miller BJ, Buckley P, Seabolt W, Mellor A, Kirkpatrick B. Meta-analysis of cytokine alterations in schizophrenia: clinical status and antipsychotic effects. Biological psychiatry. 2011;70(7):663-71

8.Guest PC. Insulin Resistance in Schizophrenia. Advances in experimental medicine and biology. 2019;1134:1-16.

9.Leonard BE, Schwarz M, Myint AM. The metabolic syndrome in schizophrenia: is inflammation a contributing cause? Journal of psychopharmacology (Oxford, England). 2012;26(5 Suppl):33-41.

10.Karanikas E, Antoniadis D, Garyfallos GD. The role of cortisol in first episode of psychosis: a systematic review. Current psychiatry reports. 2014;16(11):503

11.Hansson GK. Inflammation, atherosclerosis, and coronary artery disease. The New England journal of medicine. 2005;352(16):1685-95.

12.Ancuta P, Wang J, Gabuzda D. CDl6+ monocytes produce IL-6, CCL2, and matrix metalloproteinase-9 upon interaction with CX3CL1-expressing endothelial cells. Journal of leukocyte biology. 2006;80(5):1156-64.

13. Hansson GK. Inflammatory mechanisms in atherosclerosis. Journal of thrombosis and haemostasis : JTH. 2009;7 Suppl 1:328-31.

14.Kuvin JT, Rämeł ME, Patel AR, Pandian NG, Mendelsohn ME, Karas RH. A novel mechanism for the beneficial vascular effects of high-density lipoprotein cholesterol: enhanced vasorelaxation and increased endothelial nitric oxide synthase expression. American heart journal. 2002;144(1):165-72.

15.Kuvin JT, Patel AR, Sidhu M, Rand WM, Sliney KA, Pandian NG, et al. Relation between high-density lipoprotein cholesterol and peripheral vasomotor function. The American journal of cardiology. 2003;92(3):275-9.

16.Soria-Florido MT, Schröder H, Grau M, Fitó M, Lassale C. High density lipoprotein functionality and cardiovascular events and mortality: A systematic review and meta-analysis. Atherosclerosis. 2020;302:36-42.

17.Wang $\mathrm{P}$, Wang $\mathrm{Y}, \mathrm{Ma} \mathrm{W}$, Li $\mathrm{H}$, Chen $\mathrm{H}$. High-density lipoprotein cholesterol and intracoronary thrombosis burden. Coronary artery disease. 2013;24(1):1-5

18.Karataş $M B$, Çanga $Y$, Özcan KS, İpek G, Güngör B, Onuk T, ef al. Monocyte to high-density lipoprotein ratio as a new prognostic marker in patients with STEMI undergoing primary percutaneous coronary intervention. The American journal of emergency medicine. 2016;34(2):240-4.

19.Wu TT, Zheng YY, Chen Y, YU ZX, Ma YT, Xie X. Monocyte to highdensity lipoprotein cholesterol ratio as long-term prognostic marke in patients with coronary artery disease undergoing percutaneous coronary intervention. Lipids in health and disease. 2019;18(1):180.

20.KIZILTUNÇ E, Alsancak Y, Sezenöz B, Özkan S, Sivri S, Alsancak $A D$, et al. Relationship between monocyte/high-density lipoprotein cholesterol ratio and angiographic severity and extent of coronary artery disease. Koşuyolu Heart Journal. 2017;20(1):30-5.

21.Sahpolat $M$, Ayar D, Ari M Karaman MA. Elevated Monocyte to High-density Lipoprotein Ratios as an Inflammation Markers for Schizophrenia Patients. Clinical psychopharmacology and neuroscience : the official scientific journal of the Korean College of Neuropsychopharmacology. 2021;19(1):112-6. 
22.Association AP. Diagnostic and Statistical Manual of Mental Disorders, 4th Edition, Text Revision (DSM-IV-TR): American Psychiatric Association; 2000.

23.Sekar A, Bialas AR, de Rivera H, Davis A, Hammond TR, Kamitaki $\mathrm{N}$, et al. Schizophrenia risk from complex variation of complement component 4. Nature. 2016;530(7589):177-83.

24.Mazza MG, Capellazzi M, Lucchi S, Tagliabue I, Rossetti A, Clerici M. Monocyte count in schizophrenia and related disorders: a systematic review and meta-analysis. Acta neuropsychiatrica. 2020;32(5):229-36.

25.Weber NS, Gressitt KL, Cowan DN, Niebuhr DW, Yolken RH, Severance EG. Monocyte activation detected prior to a diagnosis of schizophrenia in the US Military New Onset Psychosis Project (MNOPP). Schizophrenia research. 2018;197:465-9.

26. Misiak B, Stańczykiewicz B, Łaczmański Ł, Frydecka D. Lipid profile disturbances in antipsychotic-naive patients with first-episode non-affective psychosis: A systematic review and meta-analysis. Schizophrenia research. 2017;190:18-27.

27.Douglas J, Nasrallah HA. Low high-density lipoprotein and psychopathology: A review. Annals of clinical psychiatry: official journal of the American Academy of Clinical Psychiatrists. 2019;31 (3):209-13.

28.Johnsen SH, Fosse E, Joakimsen O, Mathiesen EB, Stensland-Bugge E, Njølstad I, et al. Monocyte count is a predictor of novel plaque formation: a 7-year follow-up study of 2610 persons without carotid plaque at baseline the Tromsø Study. Stroke. 2005;36(4):715-9.

29. Bath PM, Gladwin AM, Martin JF. Human monocyte characteristics are altered in hypercholesterolaemia. Atherosclerosis. 1991;90(23):175-81.

30.Murphy AJ, Chin-Dusting JP, Sviridov D, Woollard KJ. The anti inflammatory effects of high density lipoproteins. Current medicinal chemistry. 2009;16(6):667-75.

31.Murphy AJ, Woollard KJ. High-density lipoprotein: a potent inhibitor of inflammation. Clinical and experimental pharmacology \& physiology. 2010;37(7):710-8

32.Açıkgöz SK, Açıkgöz E, Şensoy B, Topal S, Aydoğdu S. Monocyte to high-density lipoprotein cholesterol ratio is predictive of in-hospital and five-year mortality in ST-segment elevation myocardial infarction. Cardiology journal. 2016;23(5):505-12.

33. Yvan-Charvet L, Pagler T, Gautier EL, Avagyan S, Siry RL, Han S, et al. ATP-binding cassette transporters and HDL suppress hematopoietic stem cell proliferation. Science (New York, NY). 2010;328(5986):168993.

34. Cockerill GW, Rye KA, Gamble JR, Vadas MA, Barter PJ. Highdensity lipoproteins inhibit cytokine-induced expression of endothelial cell adhesion molecules. Arteriosclerosis, thrombosis, and vascular biology. 1995;15(11):1987-94.

35.Barter $\mathrm{P}$. The role of $\mathrm{HDL}$-cholesterol in preventing atherosclerotic disease. European Heart Journal Supplements. 2005;7(suppl_F):F4-F8.

36.Roberts CK, Ng C, Hama S, Eliseo AJ, Barnard RJ. Effect of a shortterm diet and exercise intervention on inflammatory/anti-inflammatory properties of HDL in overweight/obese men with cardiovascular risk factors. Journal of applied physiology (Bethesda, Md : 1985). 2006;101 (6):1727-32.

37.Ringen PA, Engh JA, Birkenaes AB, Dieset I, Andreassen OA Increased mortality in schizophrenia due to cardiovascular disease - a non-systematic review of epidemiology, possible causes, and interventions. Frontiers in psychiatry. 2014;5:137.

38.von Hausswolff-Juhlin $Y$, Bjartveit $M$, Lindström $E$, Jones $P$. Schizophrenia and physical health problems. Acta psychiatrica Scandinavica Supplementum. 2009 (438):15-21.

39.Onen S, Taymur I. Evidence for the atherogenic index of plasma as a potential biomarker for cardiovascular disease in schizophrenia. Journal of psychopharmacology (Oxford, England). 2021;35(9):1 120-6. 